\title{
Lead content of neuromuscular tissue in amyotrophic lateral sclerosis: case report and other considerations
}

\author{
A. PETKAU, A. SAWATZKY, C. R. HILLIER, and \\ J. HOOGSTRATEN 1 \\ The Medical Biophysics, Materials Development, and Analytical Science Branches of the \\ Whiteshell Nuclear Research Establishment, Pinawa, Manitoba, Canada
}

\begin{abstract}
Petkau, A., Sawatzky, A., Hillier, C. R., and Hoogstraten, J. (1974). British Journal of Industrial Medicine, 31, 275-287. Lead content of neuromuscular tissue in amyotrophic lateral sclerosis. Case report and other considerations. In a case of amyotrophic lateral sclerosis, in which the occupational history and laboratory evidence indicated that exposure to lead had occurred, it was found at necropsy that in tissues of nerve, spinal cord, and cardiac and skeletal muscle the lead content was $9.6 \pm 0.3,9.9 \pm 1 \cdot 7,17 \cdot 7$, and $21 \cdot 1 \pm 5 \cdot 1 \mu \mathrm{g} / \mathrm{g}$ of dry weight of tissue, respectively. Significantly elevated levels of lead were also found at necropsy in nerve, spinal cord, and muscle tissue in other cases of amyotrophic lateral sclerosis that had not been exposed to lead during life. A reassessment of the role of lead in amyotrophic lateral sclerosis is indicated.
\end{abstract}

There exist a number of published reports in which idiopathic neurological disease, such as amyotrophic lateral sclerosis (ALS) and multiple sclerosis, is linked to lead exposure (Wilson, 1907; Warren, Delavault, and Christine, 1967; Campbell, Williams, and Barltrop, 1970; Sauer, Zook, and Garner, 1970). However, analyses of postmortem tissues from patients with pathologically verified ALS have shown that the concentration of lead in muscle, spinal cord, or brain was normal and consistently low (Currier and Haerer, 1968; Barry and Mossman, 1970). This failure to obtain a correlation may be due to a number of reasons, some of them technical. It is noteworthy that the tissue specimens were often obtained many years after contact with lead had ceased (Currier and Haerer, 1968; Barry and Mossman, 1970), thus allowing time for evidence of increased lead content in the tissues largely to disappear. From this point of view the case to be ${ }^{1}$ Pathology Department, Children's Hospital, Health Sciences Centre, Winnipeg, Canada described is more suitable in that the period of exposure to white lead was relatively short and the subsequent deterioration in health comparatively rapid. The elevated lead levels found at necropsy in specimens of spinal cord, nerve, and muscle were compared to lead levels in similar tissues from two series-one, of ALS cases with no known exposure to lead, and another, of cases not involving ALS or exposure to lead. The finding that the lead content in neuromuscular tissue in the former series was higher than in the latter is, in itself, interesting and precluded a definitive assessment of the significance of the elevated lead levels in neuromuscular tissue in the case to be reported.

\section{Case report}

H. H., a 38-year-old man, first noted weakness of the right arm and hand in December 1964. About a month later he developed paraesthesiae in the fourth and fifth fingers of the right hand but they stopped after six weeks. Meanwhile there was some loss of grip power in the affected 


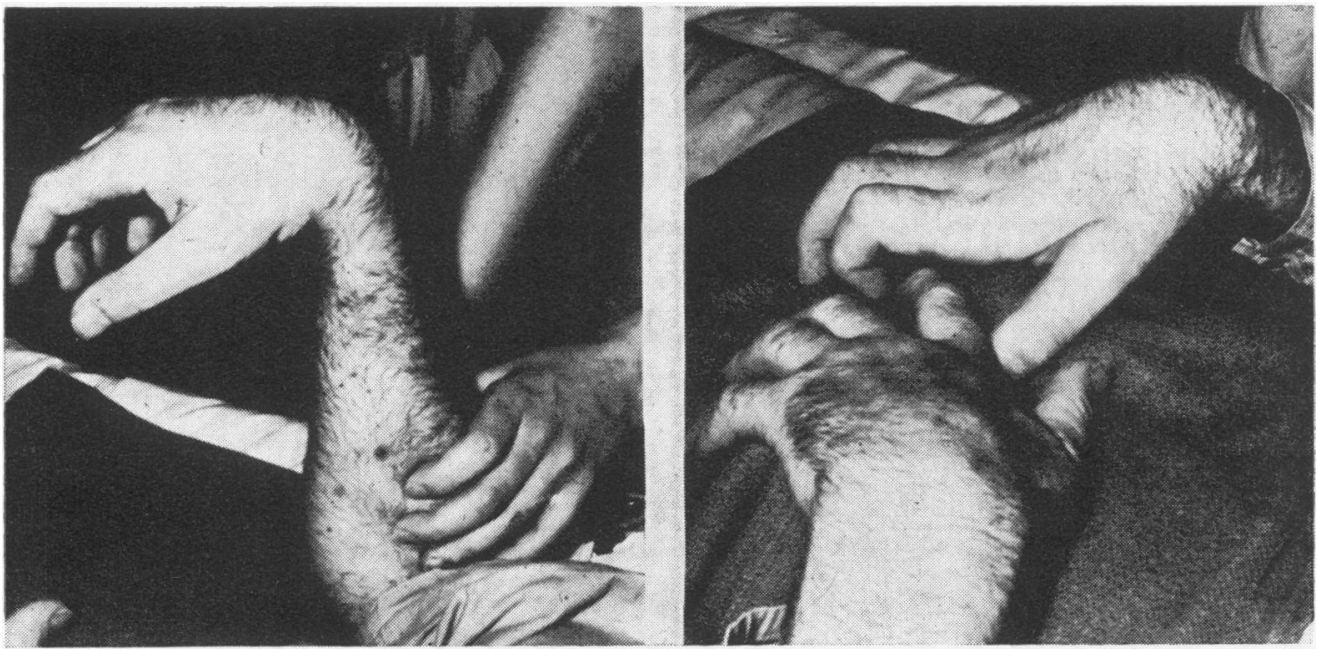

hand and the weakness spread to the elbow and shoulder. In March 1965, he was seen in a neurological and neurosurgical service and at this time there was obvious weakness of the right upper limb with some muscle wasting. Coarse fasciculations and fine fibrillations of the deltoids were also observed. The muscular weakness was most marked in the right hand. especially in the flexors and the small muscles. The flexors and extensors of the wrist were also involved, as were the biceps, triceps, and pectoral muscles. There was no sensory deficit, the cranial nerves and neck movement were normal, and the tendon reflexes were generally brisk. A cervical myelogram showed no evidence of a space-occupying lesion or of atrophy of the spinal cord. Although nerve conduction velocity measurements were not made, the electromyogram was normal. It was concluded that the patient was suffering from motor neurone disease, and he was treated with vitamin $B_{12}$. Hypertension (BP $180 / 120 \mathrm{mmHg}$ ) was unaccounted for.

At the time the patient first came to our attention in May 1965, his condition had apparently deteriorated. He complained of abdominal colic and difficulty with swallowing; he sweated easily and tended to bite his cheeks while chewing. Food would often stick in his mouth. Mentally the patient was depressed in both mood and intellectual activity, and his speech was dysarthric. There was demonstrable weakness of the orbicularis auris but the tongue extended normally and neck movements were powerful and full range. In the upper limbs muscular wasting was most marked bilaterally in the thenar and hypothenar eminences (Fig. 1) and also affected the interossei muscles. The forearms, upper arms, and shoulder girdles showed little wasting but fasciculations were prominent and there was loss of tone and power. Movement of the forearms and hands against gravity was limited to a short distance and could be sustained for a brief period only. The biceps, triceps, and supinator tendon reflexes were very brisk bilaterally. He walked with a shuffling gait. Although the tone in the lower limbs was normal, some loss of power seemed evident. Clonus was also very marked bilaterally and he had a positive Babinski on the right. The ankle and knee reflexes were pathologically brisk on both sides. There was no sensory loss.

Althouth an inquiry into the patient's occupational history had established that he had served as an oiler on a municipal dragline crew for a six-month period from June to the end of November 1964, it revealed no information that might indicate exposure to lead. Nevertheless a 24-hour urine volume from the patient was submitted to a central laboratory for analysis. The result, $0 \cdot 17 \mathrm{mg}$ $\mathrm{Pb} / \mathrm{l}$ of urine, fell within the occupationally hazardous range $(0 \cdot 15-0 \cdot 20 \mathrm{mg} / \mathrm{l})$ of the laboratory and stimulated the patient to reflect on substances that he had handled within the past year. In the event he queried the composition of the white grease he had handled without gloves during employment the previous summer and autumn. This 'grease' was in fact pure basic carbonate of lead ground in pure linseed oil.

A repeat urinalysis before chelation therapy was started gave a lead concentration of $0.05 \mathrm{mg} / \mathrm{l}$ and fell within the non-occupational range $(0.01-0.06 \mathrm{mg} / \mathrm{l})$ of the laboratory. On the second day of the first course of treatment with disodium versenate $(1 \mathrm{~g}$ iv twice daily for five days) the urinary lead level was again $0.17 \mathrm{mg} / 1$ and indicated a 24-hour excretion rate of $0.40 \mathrm{mg}$ of lead. Other laboratory data collected in May 1965 or later were as follows: Haemoglobin $13.8 \mathrm{~g} / 100 \mathrm{ml}(88.4 \%)$, haematocrit $43 \%$, MCV 85 cubic microns, MCH $25 \mathrm{pg}$, MCHC $29 \mathrm{~g} / 100 \mathrm{ml}$; no basophilic stippling, WBC $6950 / \mathrm{mm}^{3}$ with $69 \%$ polymorphs, $25 \%$ lymphocytes, $5 \%$ monocytes, and $1 \%$ eosinophils. The sedimentation rate was $31 \mathrm{~mm}$ in one hour, the platelet count 232000 , and the Wasserman reaction negative. The blood glucose 
was $100 \mathrm{mg} / 100 \mathrm{ml}$, serum iron $69 \mu \mathrm{g} / 100 \mathrm{ml}$, the BUN 17, and total coproporphyrin $277 \mu \mathrm{g} / 24$ hours (laboratory normal range $80-250 \mu \mathrm{g} / 24$ hours). The blood lead level was not determined.

From May to early August 1965 he received four courses of disodium versenate. During the first two treatments, beginning 8 May and 17 May respectively, there was objective improvement in the patient, notably in his ability to appose the forefinger and thumb of either hand, abduct and extend the fingers, extend the hands at the wrists, and raise the arms above the head from a supine position. In addition, he 'had less difficulty moving about' and was able to bath or shower, initially with assistance, and then by himself. The clonus and positive Babinski also disappeared. Following the third and fourth treatments begun on 19 June and 23 July 1965, respectively, there was no further improvement. He was subsequently transferred to a chronic care hospital where he died on 28 May 1966.

\section{Necropsy}

At necropsy ${ }^{1}$ there was bilateral pulmonary congestion, oedema, and bronchopneumonia. In addition, left ventricular hypertrophy and dilatation of both ventricles were noted. Muscular atrophy of the arms and legs was present, especially in the distal parts. The teeth were in a relatively normal state and no evidence of the blue line in the gums at the root of the teeth was seen. The tongue was normal. The heart was described as flabby and the left ventricular wall measured $2 \mathrm{~cm}$ in thickness while the right ventricular wall was $0.4 \mathrm{~cm}$ across. The circumferences of the heart valve rings were as follows: aortic $8 \mathrm{~cm}$, mitral $12 \mathrm{~cm}$, pulmonary $9 \mathrm{~cm}$, and tricuspid $15 \mathrm{~cm}$. The coronary arteries were normal and without evidence of atheroma or stenosis. The myocardium showed no evidence of past infarction although a few petechial haemorrhages were present. The abdominal organs were normal except for increased weight of some: the liver and spleen weighed 1810 and $310 \mathrm{~g}$, respective$\mathrm{ly}$; the right kidney weighed $140 \mathrm{~g}$ and the left 170 . Both were easy to decapsulate, had a smooth surface, and were congested. The brain weighed $1470 \mathrm{~g}$ and was normal externally and on section. The cerebral arteries showed no evidence of atheromatosis and the pituitary gland was also normal. The cerebrospinal fluid contained $26 \mathrm{mg} / 100 \mathrm{ml}$ urea nitrogen.

On histological examination no significant abnormality was noted in the cerebrum or cerebellum. The spinal cord exhibited loss of myelin in the lateral corticospinal tracts on both sides and this loss was accompanied by swollen perivascular microglial cells and reactive astrocytes (Fig. 2). In the anterior pyramidal tracts the loss of myelin had a patchy distribution but no comment on loss of anterior horn cells was made. Unfortunately, by the time this retrospective study focused attention on this area the

${ }^{1}$ Pathology courtesy of Dr. J. P. Brundelet. slides and the tissue blocks were no longer available. Further specific comments about the state of the anterior horn cells or on the motor cortex are therefore not possible. The skeletal muscles exhibited atrophic changes typical of nervous origin (Fig. 3) while in the heart muscle there was evidence of hypertrophy and a mild degree of interstitial oedema. The pathological diagnosis was:

(1) bilateral confluent bronchopneumonia and bilateral pulmonary congestion;

(2) left ventricular hypertrophy and dilatation; right ventricular dilatation;

(3) amyotrophic lateral sclerosis.

\section{Electron microprobe analysis}

In view of the history of lead exposure, sections of liver, spleen, kidney, pons, cerebellum, median nerve, and skeletal muscle were examined for lead with an electron microprobe, an instrument which has been used for elemental analysis of biological tissue (Mellors and Carroll, 1961; Tousimis, 1963; Carroll, Spinelli, and Goyer, 1970). No detectable amount of lead was found in any of the tissues except nerve and muscle. Samples of medium nerve and psoas muscle from other unrelated necropsies failed to show detectable quantities of lead, thus suggesting that the lead level was increased in the nerve and muscle samples obtained from the case. Use of the electron microprobe in detailed local chemical analysis of the nerve and muscle samples showed that no detectable amount of lead existed in the attached adipose tissue. The lead therefore appeared to be associated with both nerve and muscle.

Quantifying the absolute content of lead in the nerve and muscle samples by electron microprobe is hampered by various factors, such as the heterogeneous distribution of the lead and choice of suitable reference material. These factors may have been the basis for the failure to detect lead in any of the tissues other than nerve and muscle. The samples were therefore analysed for lead by emission spectrography.

\section{Emission spectrography}

In preparation for analysis by emission spectrography samples of median nerve, spinal cord, and muscle from the case were first dried at $90^{\circ} \mathrm{C}$ for 10 hours and weighed. They were then placed in separate platinum dishes and heated gradually from $100^{\circ} \mathrm{C}$ to $350^{\circ} \mathrm{C}$ in air. The temperature was raised abruptly to $550^{\circ} \mathrm{C}$, reducing each sample to approximately $1 \mathrm{mg}$. Each sample was then mixed with $3 \mathrm{mg}$ of lithium fluoride powdered buffer, packed in an ultracarbon electrode, and excited in a Jarrell Ash 3 metre Ebert mount Spectrograph. The photoplates were developed and the density of the lead line at $283.307 \mathrm{~nm}$ (2833.07 $\mathrm{A}^{\circ}$ inFigs. 4 and 5) was measured with a Jarrell Ash Microdensitometer. Figure 


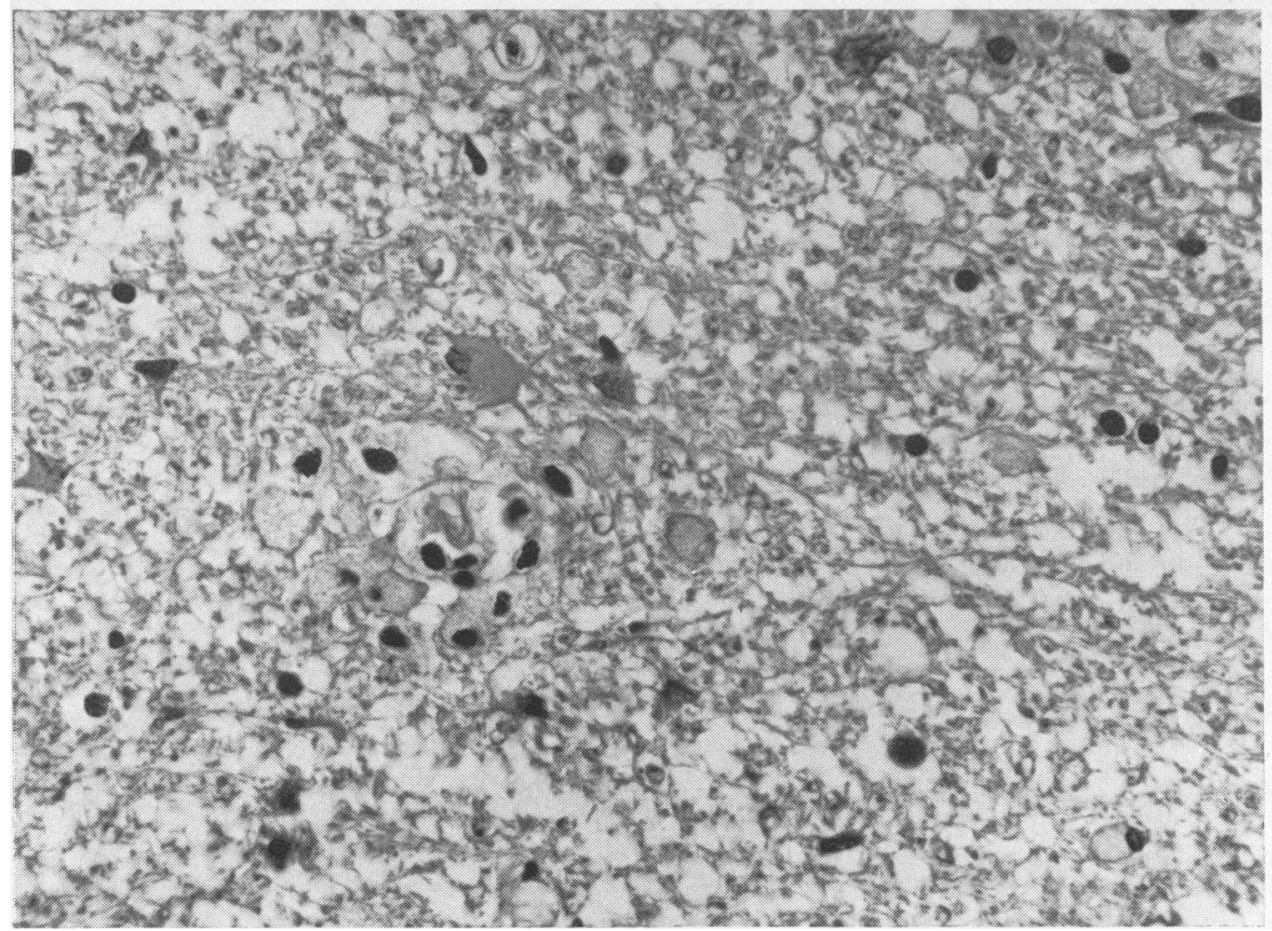

FIG. 2. Loss of myelin in lateral cortiscospinal tract accompanied by perivascular swollen microglial cells and reactive astrocytes. Haematoxylin and eosin $\times 480$.

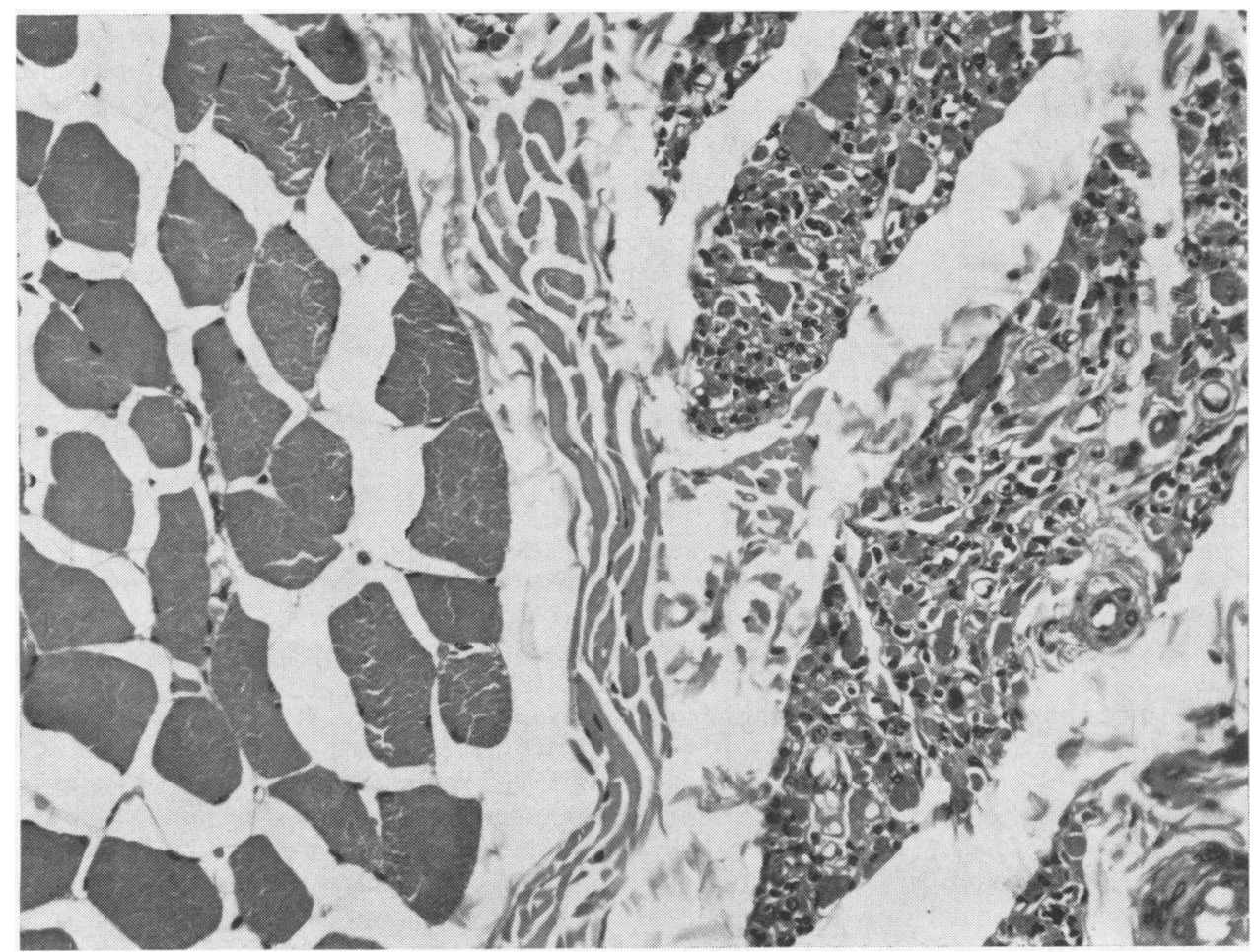

FIG. 3. Skeletal muscle showing a fascicle of normal fibres alongside a fascicle consisting of atrophic fibres. $\mathrm{H}$ and $\mathrm{E} \times 240$. 


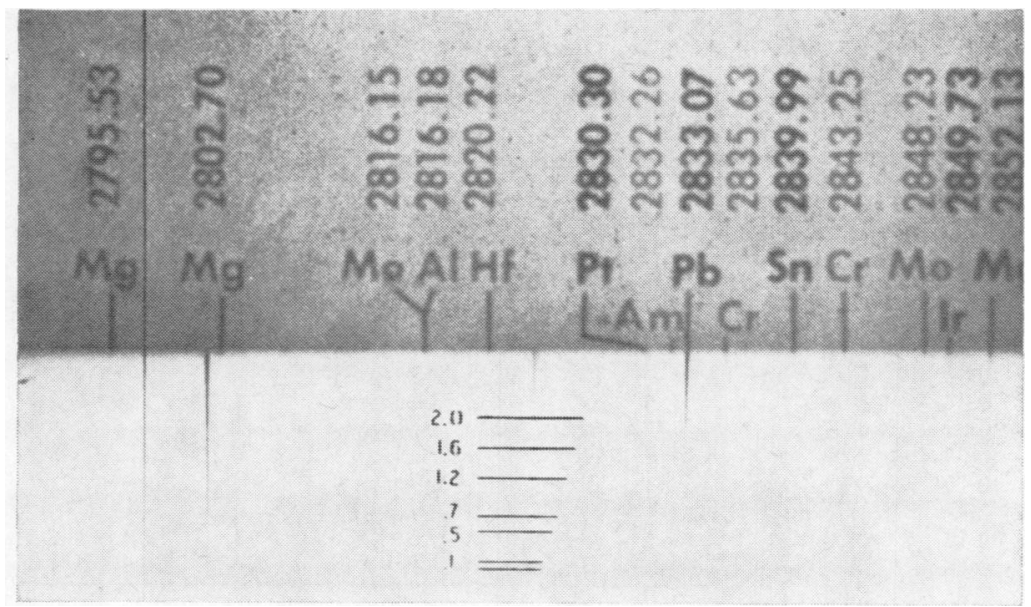

FIG. 4. Emission spectrum of a sample of the white lead used by H.H. showing the two lead lines at 280.199 and $283.307 \mathrm{~nm}$ (2801.99 and

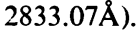

4 shows a portion of the $235.00-435.00 \mathrm{~nm}$ emission spectrum obtained after exciting a small sample of the pure white lead (carbonate) that the patient had been exposed to in 1964. It shows only the lead lines at 280.199 and $283.307 \mathrm{rm}$ and indicates the purity of the lead to which the patient was exposed. Figure 5 is a record of a portion of the emission spectrum of a sample of muscle that contained $27 \mu \mathrm{g}$ of lead per gram of dry weight. It was found that the mean lead content $(\mu \mathrm{g} / \mathrm{g}$ dry weight of tissue) of nerve, cervical segment of spinal cord, heart muscle, and skeletal muscle was $9 \cdot 6 \pm 0 \cdot 3,9 \cdot 9 \pm 1 \cdot 7,17 \cdot 7$, and $21 \cdot 2 \pm 5 \cdot 1$, respectively. Similar analysis of the standard materials used to fix the specimens failed to show detectable quantities of lead and therefore established that the lead was associated with the tissue. These data show that in this case the lead levels in nerve, muscle, and spinal cord were comparable in magnitude to those found in similar tissues many years ago in a particular case of lead paralysis (Herter, 1895).

\section{Lead in ALS and control groups}

A lead content $(\mu \mathrm{g} / \mathrm{g}$ dry weight) of $17 \cdot 7$ and 21.2 in heart and skeletal muscle, respectively, is much higher than the recently reported values of $0 \cdot 26-0 \cdot 30$ in either muscle for a large series of necropsies not involving ALS or known exposure to lead (Barry and Mossman, 1970; Soman et al., 1970). This observation combined with the need for more data on the lead content of spinal cord and nerve tissue suggested measurements by emission spectrography of the lead present in nerve, cervical segment of spinal cord, and skeletal muscle tissue in two series-one involving ALS (ALS group), and another not involving either ALS or known lead exposure (control group). For the latter group specimens from 12 necropsies were obtained and the data are given in Table 1. It may be noted that in this mixed group the mean value for the lead content in muscle compares with that reported from several large series (Barry and Mossman, 1970) after the latter data have been

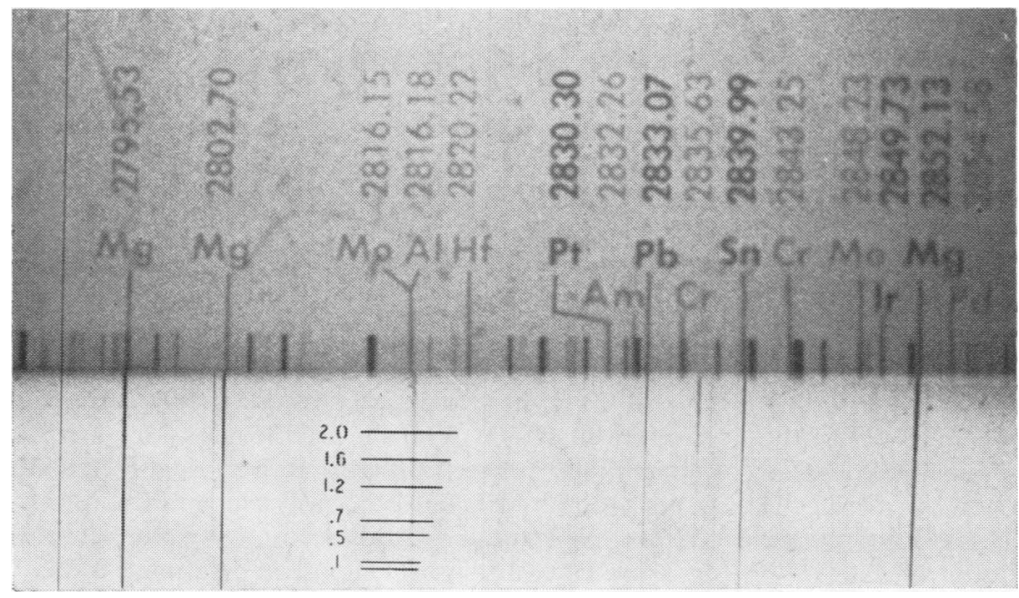

FIG. 5. A portion of the emission spectrum of a sample of skeletal muscle obtained from H.H. at necropsy. The two lead lines at 280.199 and $283.307 \mathrm{~nm}$ are clearly seen. The intensity of the latter corresponded to a lead content of $27 \mu \mathrm{g} / \mathrm{g}$ of dry weight of tissue. 
TABLE 1

Tissue Lead Concentration $(\mu \mathrm{g} / \mathrm{g}$ Dry

WeIGHT OF TISSUE)

IN NoN-EXPOSED (CONTROL) GrouP

\begin{tabular}{|c|c|c|c|c|c|}
\hline \multirow{2}{*}{$\begin{array}{l}\text { Case } \\
\text { No. }\end{array}$} & \multirow{2}{*}{$\begin{array}{l}\text { Age } \\
(y r)\end{array}$} & \multirow{2}{*}{ Sex } & \multicolumn{3}{|c|}{ Tissue } \\
\hline & & & Nerve & $\begin{array}{l}\text { Spinal } \\
\text { cord }\end{array}$ & Muscle \\
\hline $\begin{array}{r}1 \\
2 \\
3 \\
4 \\
5 \\
6 \\
7 \\
8 \\
9 \\
10 \\
11 \\
12\end{array}$ & $\begin{array}{l}3 \mathrm{mth} \\
6 \mathrm{mth} \\
14 \\
38 \\
41 \\
55 \\
63 \\
65 \\
76 \\
86 \\
86 \\
92\end{array}$ & $\begin{array}{l}\mathbf{F} \\
\mathbf{M} \\
\mathbf{M} \\
\mathbf{M} \\
\mathbf{F} \\
\mathbf{F} \\
\mathbf{M} \\
\mathbf{F} \\
\mathbf{M} \\
\mathbf{M} \\
\mathbf{M} \\
\mathbf{M}\end{array}$ & $\begin{array}{l}1.4 \\
0.6 \\
0.11 \\
0.21 \\
0.12 \\
0.28 \\
6.9 \\
0.21 \\
0.4 \\
1.8 \\
0.8 \\
0.43\end{array}$ & $\begin{array}{l}0.3 \\
0 \cdot 08 \\
0.08 \\
0 \cdot 07 \\
0 \cdot 07 \\
0 \cdot 10 \\
2 \cdot 3 \\
0 \cdot 12 \\
0 \cdot 10 \\
0 \cdot 2 \\
0 \cdot 1 \\
0 \cdot 09\end{array}$ & $\begin{array}{l}0.12 \\
0.7 \\
\quad-\overline{0} \\
0.07 \\
0.08 \\
0.09 \\
1.7 \\
0.05 \\
0.2 \\
0.05 \\
0.7 \\
0.06\end{array}$ \\
\hline \multicolumn{3}{|c|}{$\begin{array}{r}\text { Mean } \\
\text { Standard deviation }\end{array}$} & $\begin{array}{l}1 \cdot 1 \\
1.9\end{array}$ & $\begin{array}{l}0.3 \\
0.7\end{array}$ & $\begin{array}{l}0.3 \\
0.5\end{array}$ \\
\hline
\end{tabular}

converted to $\mu \mathrm{g} / \mathrm{g}$ dry weight of tissue (Soman etal., 1970). For the ALS series, two biopsy specimens and tissues from three necropsies were available and the data on their lead levels are given in Table 2. It was found that in this group the lead content in the three classes of tissues was elevated and, in nerve and spinal cord, compared with those found in the H.H. case. The muscle tissue from the latter contained more lead than similar tissue from the other five in the ALS group, and this difference was statistically significant at the $P<0.01$ level.

A statistical analysis of the data in Tables 1 and 2 was performed using the $t$ test for unpaired variates. For this purpose, only the paediatric entries in the control group (first three, Table 1) were eliminated since it is known that the lead content of soft tissues may increase in the first two decades of life but in muscle and brain tissues at any rate there is little or no difference between male and female adults (Barry and Mossman, 1970). The results of the analysis are given in Table 3 where the unbracketed $P$ values show that the difference in lead content of nerve, spinal cord, and muscle in the ALS group is significantly higher than in the control group. The bracketed $P$ values give the level of significance of the difference between the means when the H.H. case is excluded from the ALS group. It is seen that the lead content of nerve and spinal cord is still significantly elevated in the ALS group and that the most significant difference occurs in skeletal muscle. Analytically, the latter result is a consequence of the earlier observation that in the H.H. case the muscle tissue contained a much larger amount of lead.
TABLE 2

Tissue Lead Concentration $(\mu \mathrm{g} / \mathrm{g}$ DRY WEIGHT OF TISSUE) IN AMYOTROPHIC LATERAL SCLERosis

\begin{tabular}{|c|c|c|c|c|c|c|}
\hline \multirow{2}{*}{ Case } & \multirow{2}{*}{ Age } & \multirow{2}{*}{ Sex } & \multicolumn{4}{|c|}{ Tissue } \\
\hline & & & Source & Nerve & $\begin{array}{l}\text { Spinal } \\
\text { cord }\end{array}$ & Muscle \\
\hline $\begin{array}{c}1 \\
2 \\
3 \\
4 \\
5 \\
\text { H.H. }\end{array}$ & $\begin{array}{l}66 \\
75 \\
39 \\
72 \\
72 \\
38\end{array}$ & $\begin{array}{l}\mathbf{F} \\
\mathbf{M} \\
\mathbf{M} \\
\mathbf{M} \\
\mathbf{M} \\
\mathbf{M}\end{array}$ & $\begin{array}{l}\text { Necropsy } \\
\text { Necropsy } \\
\text { Necropsy } \\
\text { Biopsy } \\
\text { Biopsy } \\
\text { Necropsy }\end{array}$ & $\begin{array}{l}\frac{9 \cdot 7}{2 \cdot 1} \\
\frac{-}{9 \cdot 6}\end{array}$ & $\begin{array}{r}3 \cdot 9 \\
14 \cdot 3 \\
1 \cdot 3 \\
- \\
\overline{9} \cdot 9\end{array}$ & $\begin{array}{r}3.5 \\
3.6 \\
0.9 \\
3.9 \\
5.9 \\
21.1\end{array}$ \\
\hline \multicolumn{3}{|c|}{$\begin{array}{c}\text { Mean } \\
\text { Standard deviation }\end{array}$} & & $\begin{array}{l}7 \cdot 1 \\
4 \cdot 3\end{array}$ & $\begin{array}{l}7 \cdot 4 \\
5 \cdot 8\end{array}$ & $\begin{array}{l}6 \cdot 5 \\
7 \cdot 4\end{array}$ \\
\hline
\end{tabular}

TABLE 3

COMParison OF Tissue Lead CONCENTRation
$(\mu \mathrm{g} / \mathrm{g}$ DRY Weight OF TISSUE) IN AMYotrophic Lateral Sclerosis (ALS) and Control Groups: Male and Female ADULTS

\begin{tabular}{|c|c|c|c|c|c|}
\hline \multirow[b]{2}{*}{ Tissue } & \multicolumn{2}{|r|}{$A L S$} & \multicolumn{2}{|r|}{ Control } & \multirow[b]{2}{*}{$\mathbf{P}$} \\
\hline & $N$ & $\begin{array}{c}\text { Mean } \\
( \pm \sigma)\end{array}$ & $N$ & $\begin{array}{c}\text { Mean } \\
( \pm \sigma)\end{array}$ & \\
\hline $\begin{array}{l}\text { Nerve } \\
\text { Spinal cord } \\
\text { Muscle }\end{array}$ & $\begin{array}{l}3 \\
4 \\
6\end{array}$ & $\begin{array}{l}7 \cdot 1(4 \cdot 3) \\
7 \cdot 4(5 \cdot 8) \\
6 \cdot 5(7 \cdot 4)\end{array}$ & $\begin{array}{l}9 \\
9 \\
9\end{array}$ & $\begin{array}{l}1.2(2.2) \\
0.4(0.7) \\
0.3(0.5)\end{array}$ & $\begin{array}{l}<0.01(<0.05)^{1} \\
<0.01(<0.02)^{1} \\
<0.05(<0.001)^{1}\end{array}$ \\
\hline
\end{tabular}

IIf the H.H. case from the ALS group is excluded

\section{Discussion}

It is tempting to ascribe the signs and symptoms of the present case to lead intoxication, particularly in view of the temporal relationship between the onset of the patient's disease and his contact with lead carbonate. The association is further strengthened by the early development of finger and wrist drop, characteristic of lead poisoning (Robbins, 1963), as well as by the positive lead mobilization test (Přerovská and Teisinger, 1970) and the clinical improvement following chelation therapy. Furthermore, the early onset and rapid progression of the disease is uncharacteristic of ALS, while the type of localized loss of myelin of motor nerve fibres seen in this case has been attributed to lead toxicity (Gombault, 1873). The elevated levels of lead in the spinal cord, nerve, and muscle are also consistent with this diagnosis, and the polyneuropathy, related to lead poisoning, would account for the clinical evidence of lower motor neurone disease as well. 


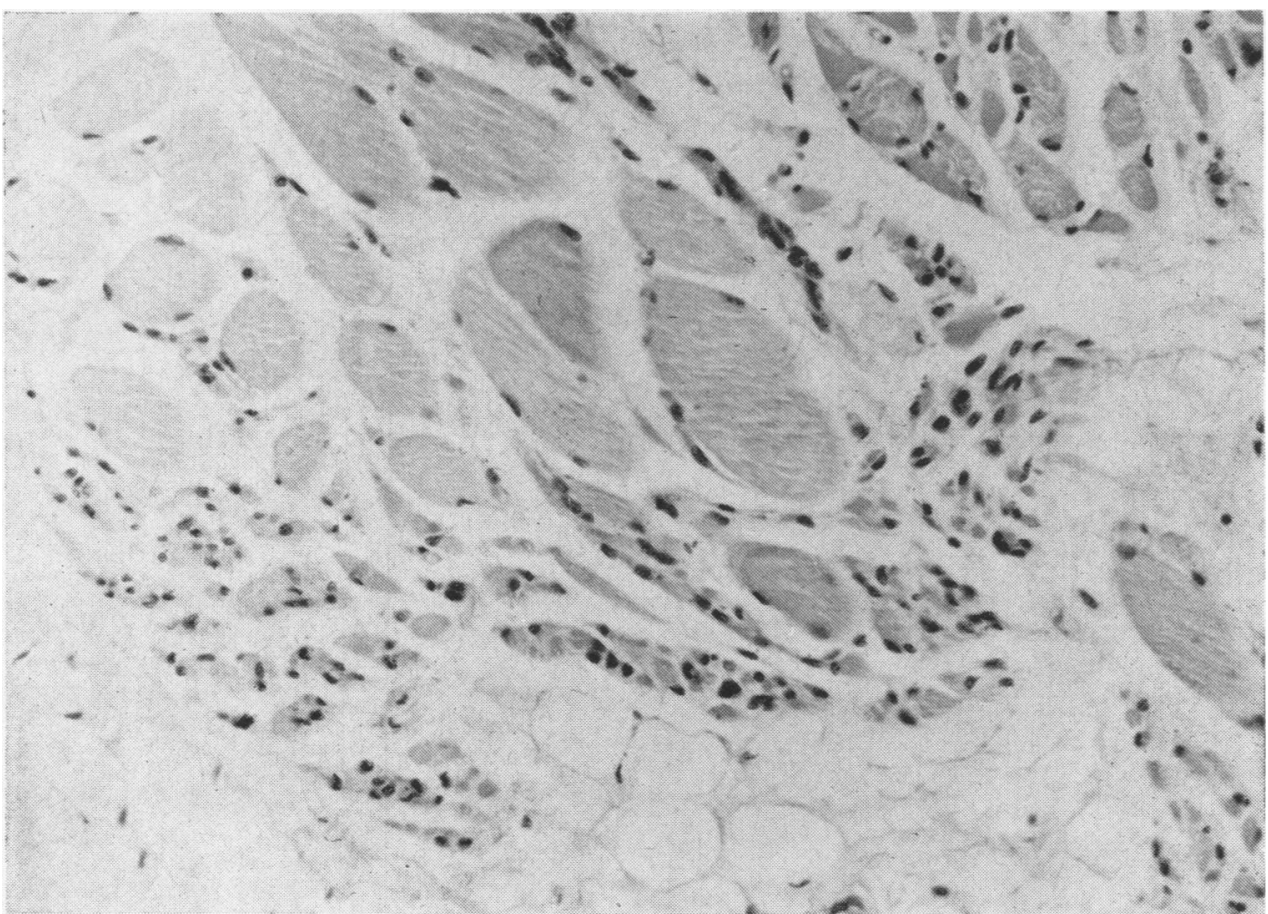

FIG. 6. Fascicles of atrophic muscle fibres within the tongue of case 1 of ALS group, Table 2. $H$ and $E \times 255$.

The clinical signs of bulbar palsy, pyramidal tract involvement, and the normal electromyogram are also consistent with lead poisoning(Simpson, Seaton, and Adams, 1964; Campbell et al., 1970), although the partial and only transient recovery following chelation therapy contrasts with the much better result obtained elsewhere (Simpson et al., 1964). Nevertheless failure of lead-poisoned patients to respond to chelation therapy has been noted before (Campbell et al., 1970).

However, the unexpected finding of elevated lead levels in neuromuscular tissue from the ALS group (Table 2) made the diagnosis of lead poisoning in the H.H. case uncertain and initiated a re-examination (by J.H.) of the neuropathology in this group using available necropsy material (cases 1, 2, and 3; Table 2).

In case 1, the spinal cord of this 66-year-old housewife exhibited pallor of the lateral corticospinal tracts with slight microgliosis. The medullary pyramids were not involved. There was marked and unequivocal neuromuscular atrophy of the tongue (Fig. 6) but the hypoglossal nucleus looked normal.

In case 2 , there was no convincing evidence of cortical neuronal disease in this 75-year-old pensioner. Interpretation of this fact must be qualified by the uncertainty in the identification of the portion of the motor cortex that was sectioned at necropsy. There was loss of myelin in the medullary pyramids as well as decussation and prominent pallor of the lateral corticospinal tracts throughout the length of the spinal cord (Fig. 7). No firm evidence of anterior horn cell disease was found other than the presence of lipofuscin. The hypoglossal nucleus appeared normal but a section of tongue was not available. Atrophic muscle fibres were present in the left arm and to a lesser degree in the right. The atrophic fibres lay within fascicles that contained fibres of normal size. Similar changes were noted in the muscles of the lower limbs. Since no firm evidence of anterior horn cell disease was found the significance of the isolated muscle fibre atrophy is uncertain because similar changes occur through disuse in elderly debilitated patients.

The third case (3, Table 2) was that of a 38-year-old hydro labourer. This man exhibited pallor of both the medullary pyramids (Fig. 8) and the lateral corticospinal tracts (Fig. 9). Both regions contained perivascular accumulations of swollen microglial cells (Figs. 10 and 11), as did the anterior horns. There was a paucity of anterior horn cells (Fig. 12). In the hypoglossal nucleus a neurone was found to contain a large eosinophillic cytoplasmic inclusion body (Fig. 13). No muscle material was available. Although no sections of muscle could therefore be examined, from the extensive loss of myelin in the 


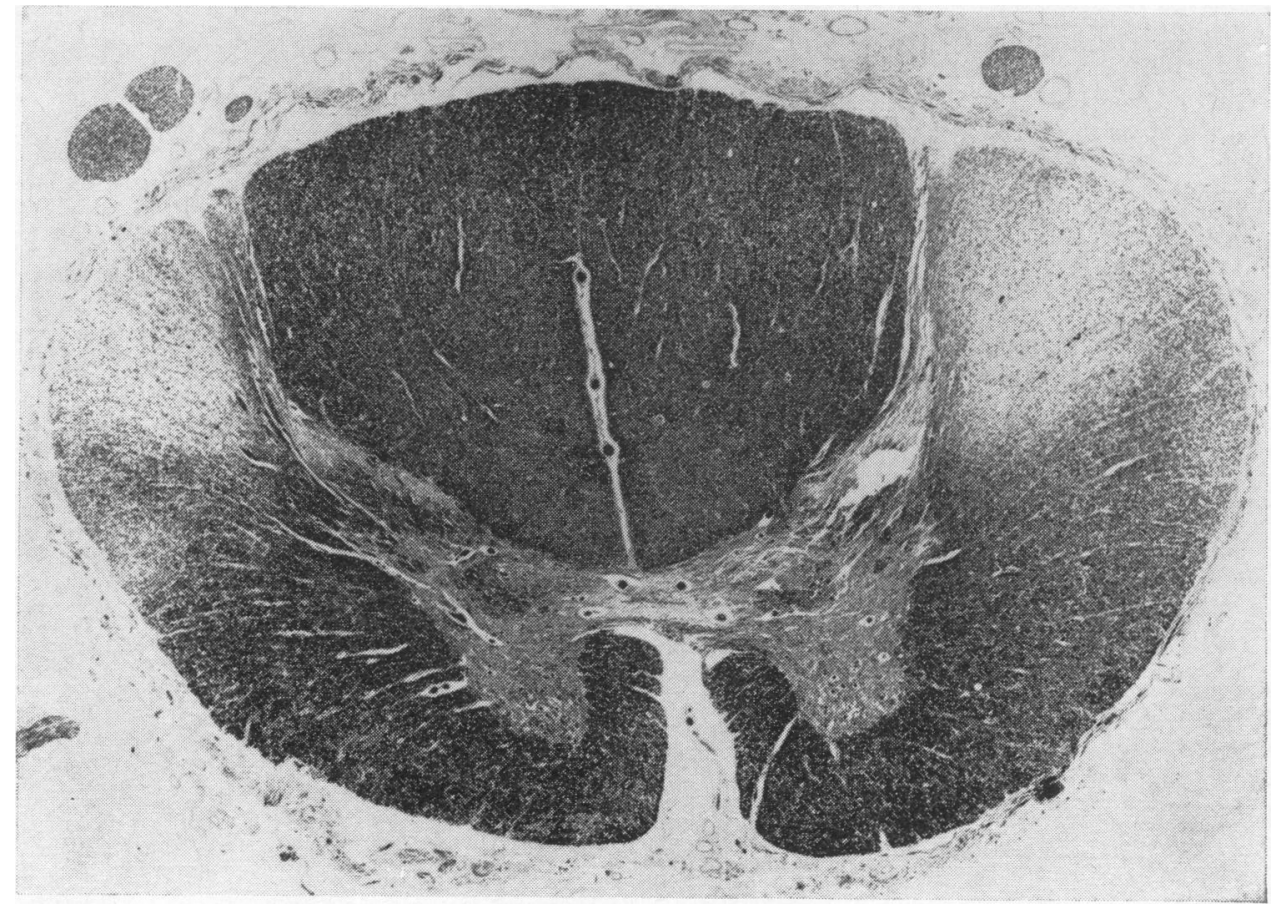

FIG. 7. Section of spinal cord of case 2 of ALS group, Table 2, showing pallor of the lateral corticospinal tracts and the spinothalamic tracts. Luxol fast blue stain $\times 15$.

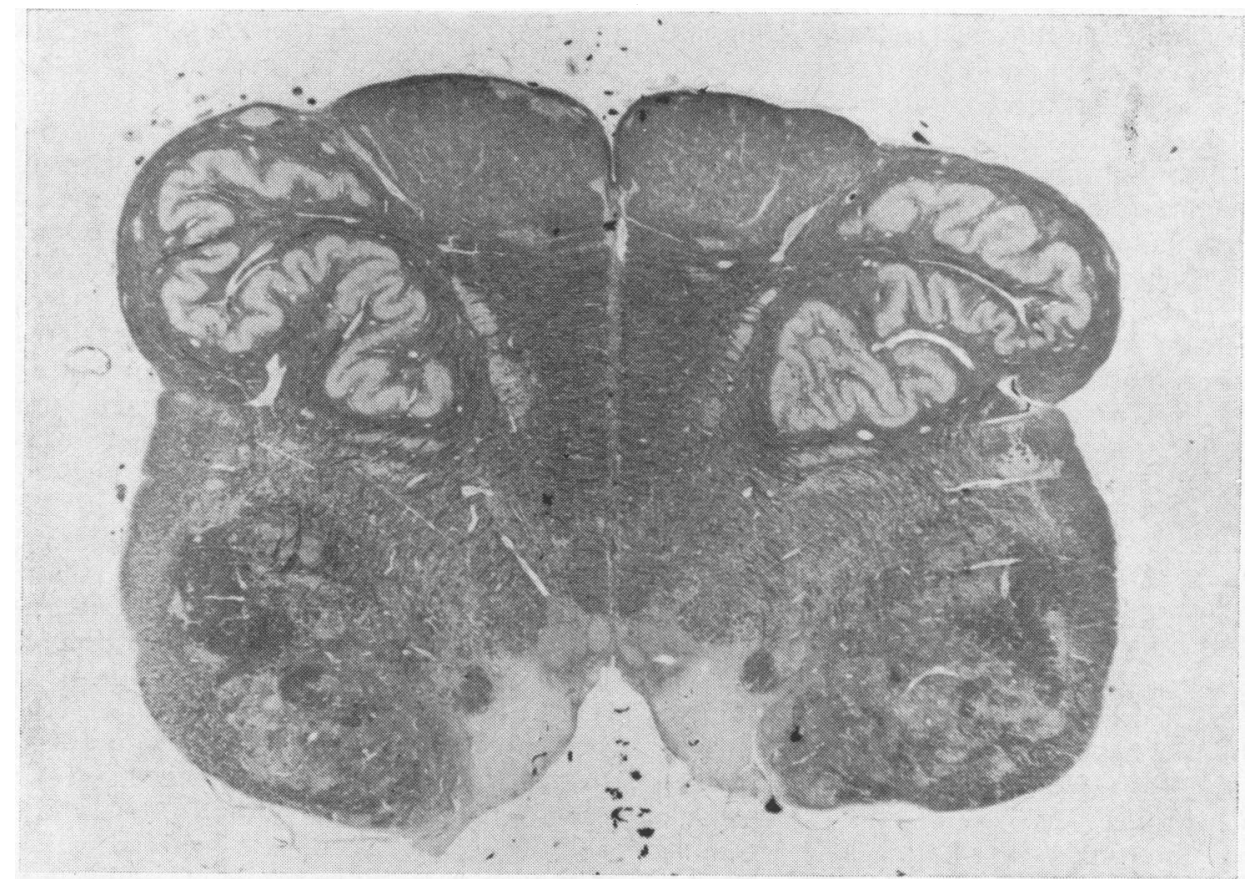

FIG. 8. Section of medulla of case 3 of ALS group, Table 2, showing moderate pallor of pyramids. Woelcke stain $\times 8$. 


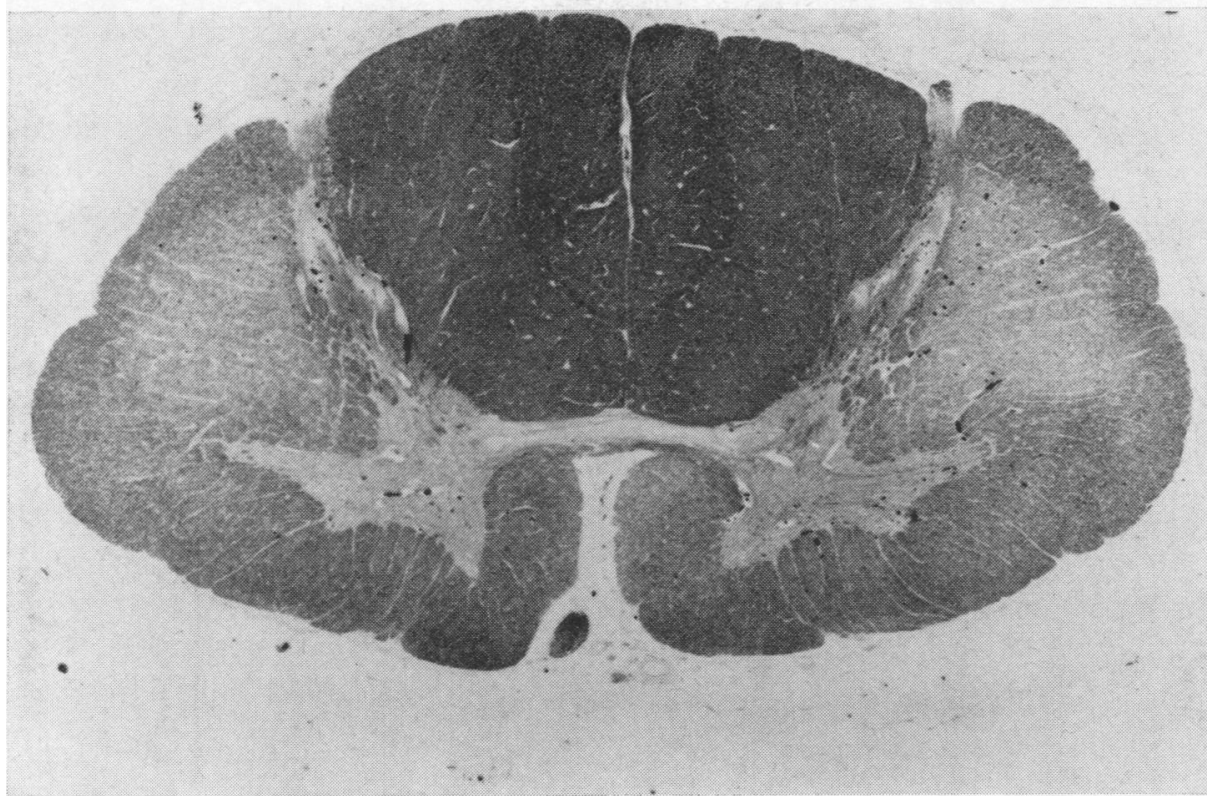

FIG. 9. Section of spinal cord of case 3 of ALS group, Table 2, showing pallor of the lateral corticospinal tracts. Woelcke stain $\times 8$.

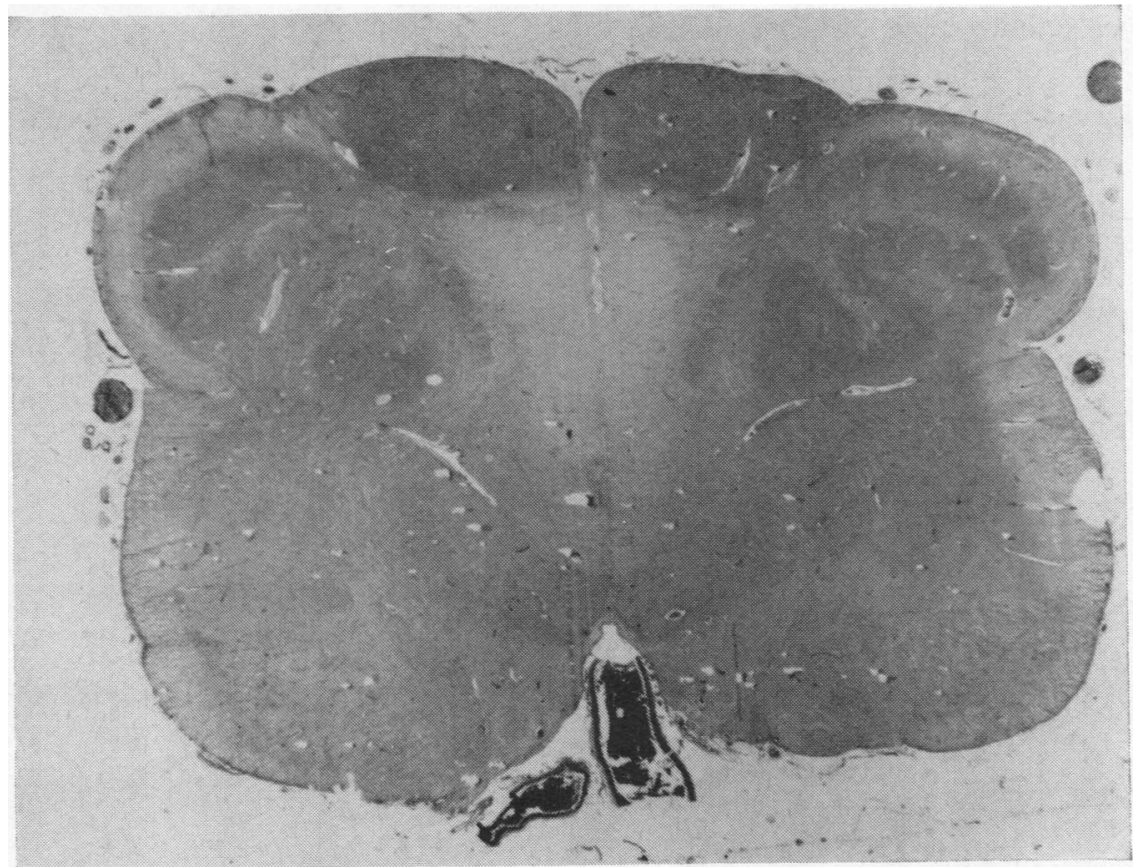

FIG. 10. Section of medulla of case 3 of ALS group, Table 2, showing moderate gliosis of pyramids. Holzer stain $\times \mathbf{9 \cdot 8}$. 


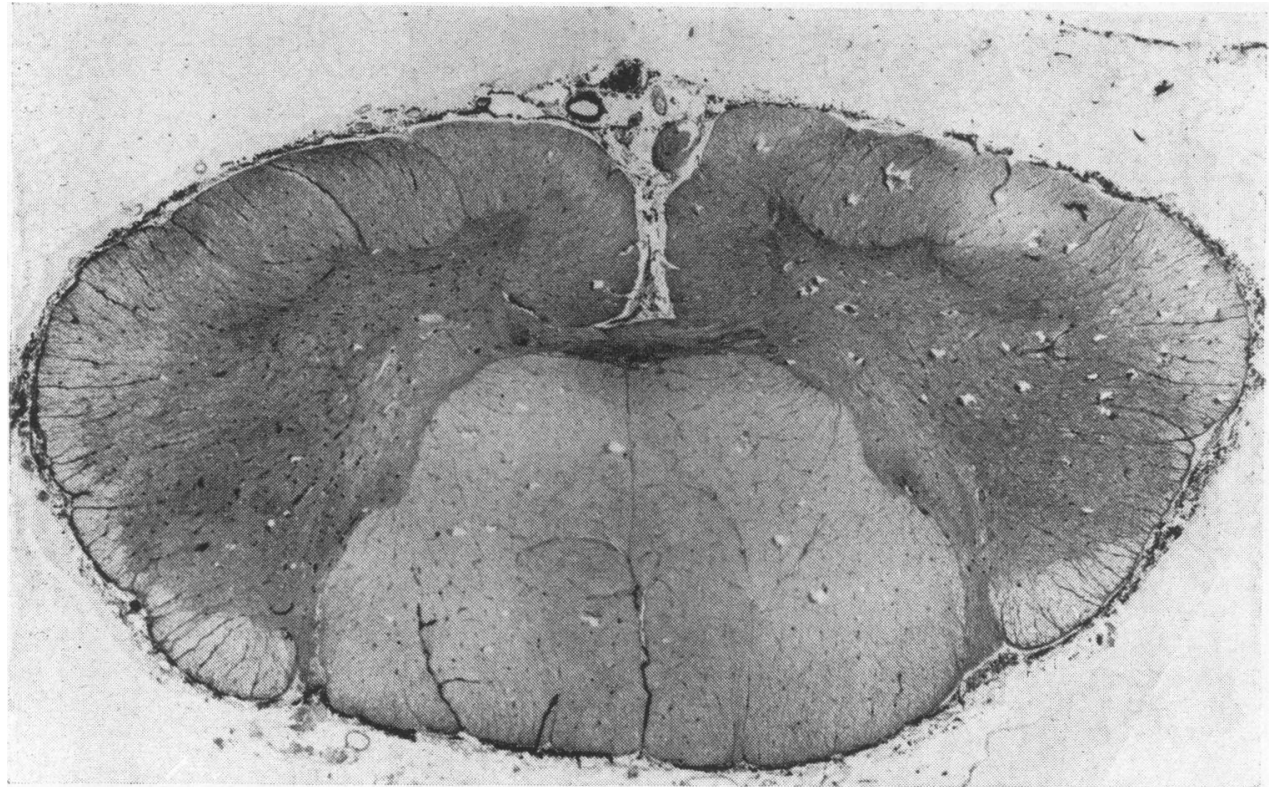

FIG. 11. Section of spinal cord of case 3 of ALS group, Table 2, showing moderate gliosis of anterior horns and pallor of lateral corticospinal tracts. Holzer stain $\times \mathbf{9 . 8}$.

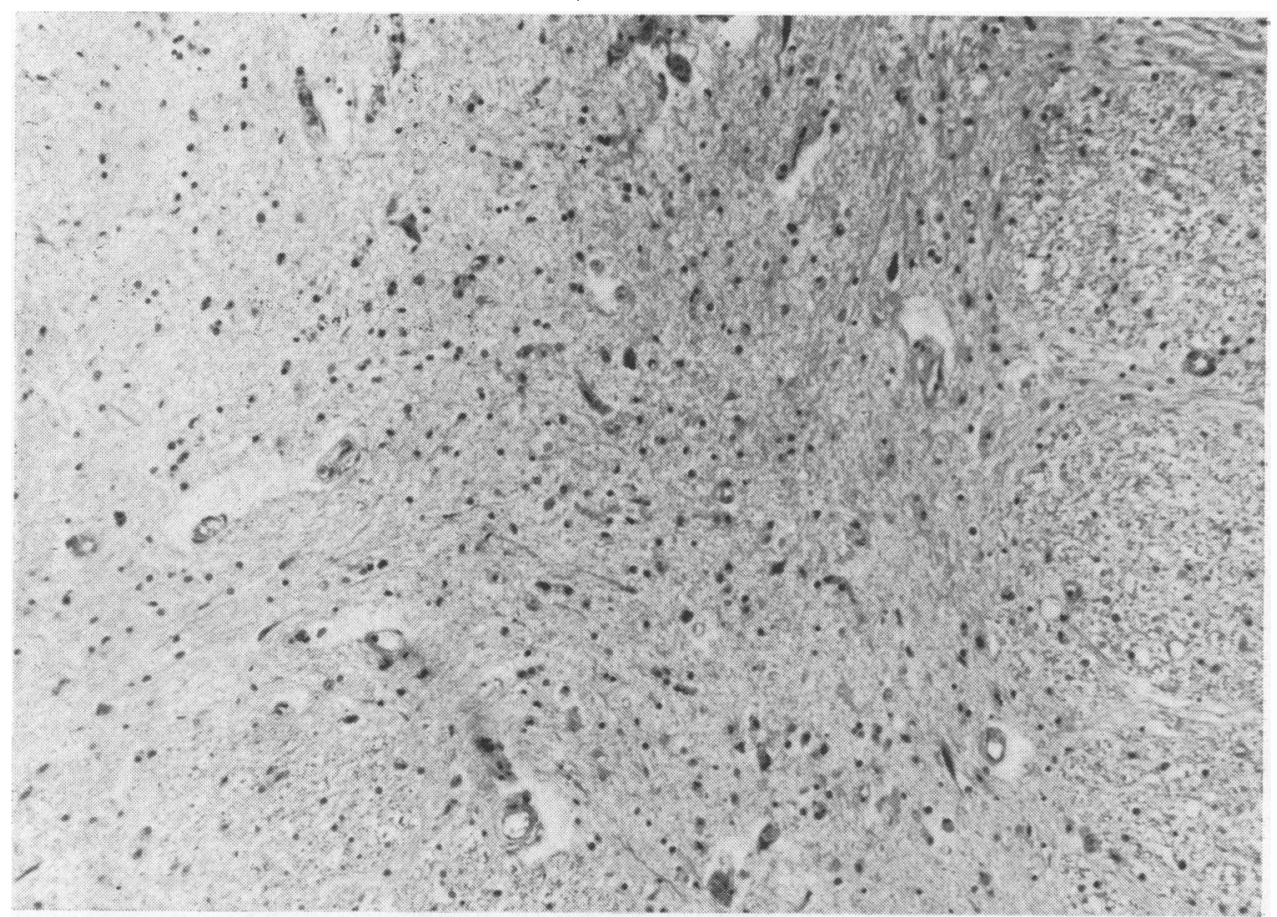

FIG. 12. Section of spinal cord of case 3 of ALS group, Table 2, showing paucity of neurons. Those that remain are small. $\mathrm{H}$ and $\mathrm{E} \times 130$. 


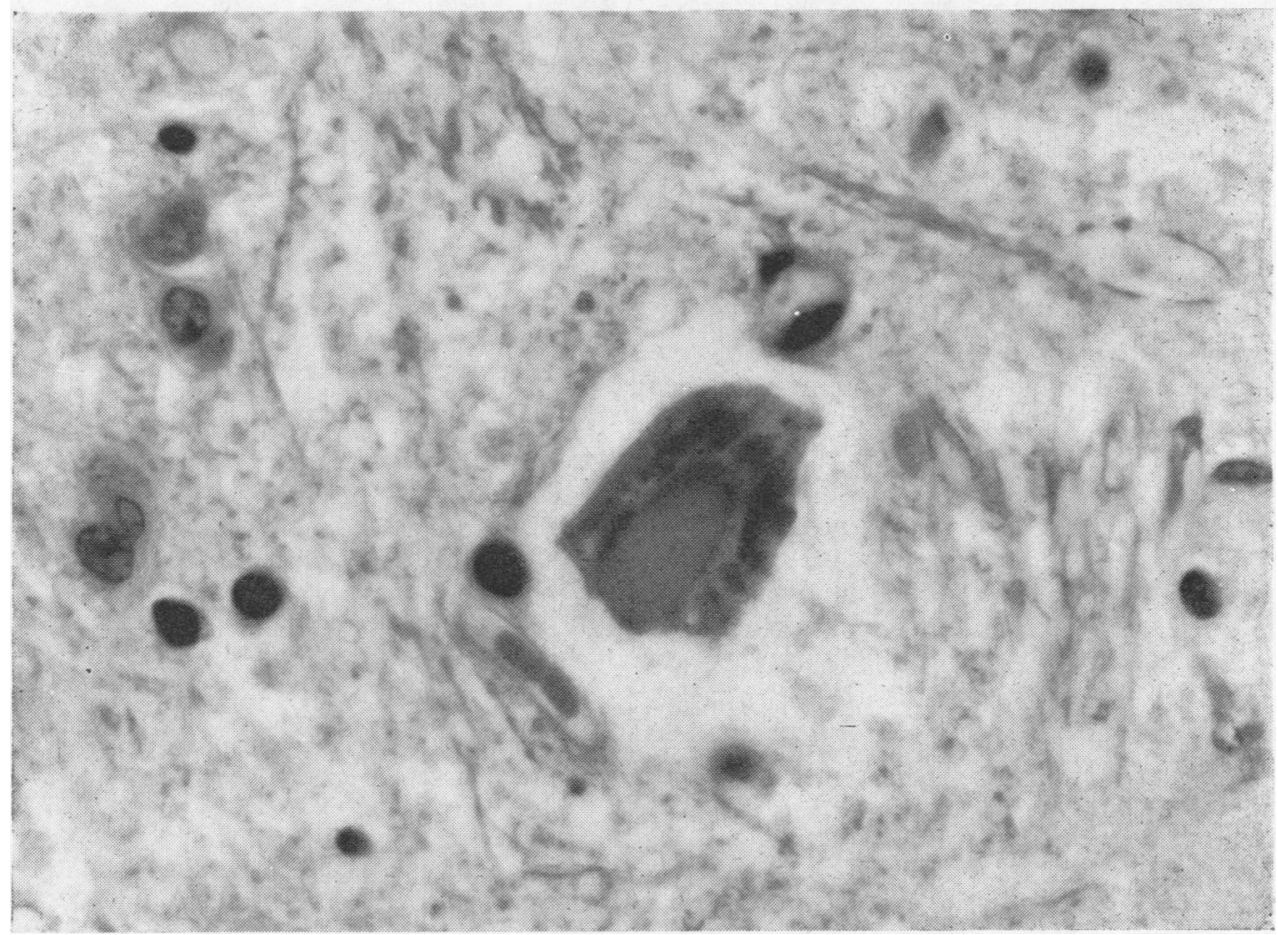

FIG. 13. Section of hypoglossal nucleus of case 3 of ALS group, Table 2, showing a large intracytoplasmic eosinophilic inclusion within a neuron. The Nissl substance is clumped and displaced to the periphery. $\mathrm{H}$ and $\mathrm{E} \times 1025$.

pyramids and lateral corticospinal tracts, along with the loss of anterior horn cells and the gliosis, the diagnosis of amyotrophic lateral sclerosis seems unequivocal.

It is reasonable to query to what extent the elevated lead content in neuromuscular tissue may have contributed to the course of the disease in the ALS group. On the other hand, the elevated lead levels may be the consequence of the disease due to some impairment of normal lead detoxification and excretion mechanisms. In this connection it may be noted that no evidence of liver or kidney damage was apparent in the H.H. case although the unexplained hypertension might possibly have been due to some subtle changes in renal structure or function at the mitochondrial level (Goyer and Krall, 1969).

The particular sensitivity of the human central nervous system to the toxic effects of lead (Goyer et al., 1970) may represent a direct clinical indicator that neuromuscular tissue has a peculiar affinity for the metal. If so, then more data on lead levels in neuromuscular tissue in demyelinating diseases is required to establish the relationship. The affinity of red cell (Patterson, 1965; Haeger-Aronsen, 1971) and mitochondrial (White and Harvey, 1972) membranes for lead has been noted and discussed in terms of its biochemical and chemical reactivity with sulphydryl groups (Přerovská and Teisinger, 1970; Chisolm, 1971). Although an earlier report, based on two cases, suggests that the concentration of lead in nerve tissue in ALS may be normal (Currier and Haerer, 1968), the present data suggest that it can be otherwise, at least in some cases. While both methods of analysis employed a spectrochemical technique (Kehoe, Cholak, and Story, 1940; Kehoe, 1964; Currier and Haerer, 1968) the apparent contradiction may not be real for reasons given in the introductory remarks and because of the fact that it has long been recognized that the response to lead varies from one individual to another (Cantarow and Trumper, 1944; Lane, 1949). The extent to which dietary habits, infections (Weiner, Johnson, and Herndon, 1973), malnutrition, anaemia (Goyer, 1971), and metabolic factors determine the degree of susceptibility is poorly understood. However, the recently reported data, relating elevated lead levels to an enzyme deficiency (glucose-6-phosphate dehydrogenase (McIntire and Angle, 1972)), are indicative of the manner in which genetic factors may contribute to the variable susceptibility. Genetically 
determined differences in frequency and distribution of 'protective' sulphydryl groups near the active site of sulphydryl-containing enzymes or other receptor proteins important to electrophysiological function may be another basis for variability in sensitivity to the toxic effects of lead. Associated conformational differences may affect the extent to which these molecules are then accessible to chelates and thus determine the variable effectiveness of chelation therapy (Campbell et al., 1970).

In view of the increased amount of lead present in neuromuscular tissue in the ALS group it will be of interest to determine in what cellular structures the metal is concentrated. In association with the cell membrane a structural basis for the obvious disruption of neuromuscular function would be provided. On the other hand, experimental evidence suggests that lead binds to the endoplasmic reticulum (Choie and Richter, 1972) and affects mitochondria (Koeppe and Miller, 1970; Cardona, Lessler, and Brierley, 1971). The latter effect is particularly interesting, not only because it is accentuated during inorganic phosphate deficiency, but also because it disrupts the fundamental reactions of energy transduction and tissue respiration. In animals this results in elevated norepinephrine levels (Krall, Pesavanto, Harmon, and Packer, 1972), an observation that might have some relevance in accounting for the hypertension in the H.H. case.

From the foregoing remarks it is clear that the biochemical and physiological consequences of increased tissue lead levels are several and varied. To establish the extent to which these effects are manifest in cases of ALS, in which the lead content in neuromuscular tissue may be shown to be elevated, more investigative work will be required in the direction suggested by this report. Adequate clinical material seems to be available (Bobowick and Brody, 1973). The present data imply that with accurate and sensitive techniques the measurement of an elevated lead content in muscle biopsy material from ALS patients is possible and worthwhile in order to determine the incidence of enhanced lead uptake in ALS and to establish whether the lead accumulation is antecedent to, or a consequence of, the ALS disease process. A spectrochemical method of analysis is particularly appropriate for this purpose in that it makes it possible to relate the findings to tissue levels of other constituents important in lead metabolism, such as inorganic phosphate and copper. Analyses of this type on cerebrospinal fluid in the course of establishing the diagnosis in such cases might also prove worthwhile. When supplemented by similar measurements on neuromuscular tissue obtained at necropsy it is likely that the nature of the relationship between ALS and elevated lead levels will be more accurately understood than at present.
We are indebted to Mrs. Maria McAllister, Municipal Hospitals, Winnipeg, Canada, for making the postmortem material in the H.H. case available to us; to Dr. M. Hamonic, St. Boniface Hospital, Winnipeg, Canada, for providing all the other necropsy material; and to $S$. Jones, Whiteshell Nuclear Research Establishment for doing the tissue analyses by electron microprobe.

\section{References}

Barry, P. S. I. and Mossman, D. B. (1970) Lead concentrations in human tissues. British Journal of Industrial Medicine, 27, 339-351.

Bobowick, A. R. and Brody, J. A. (1973). Epidemiology of motor-neurone diseases. New England Journal of Medicine, 288, 1047-1055.

Campbell, A. M. G., Williams, E. R., and Barltrop, D. (1970). Motor neurone disease and exposure to lead. Journal of Neurology, Neurosurgery and Psychiatry, 33, 877-885.

Cantarow, A. and Trumper, M. (1944). Lead Poisoning. Williams and Wilkins, Baltimore.

Cardona, E., Lessler, M. A., and Brierley, G. P. (1971). Mitochondrial oxidative phosphorylation: interaction of lead and inorganic phosphate. Proceedings of the Society for Experimental Biology and Medicine, 136, 300-304.

Carroll, K. G., Spinelli, F. R., and Goyer, R. A. (1970). Electron probe microanalyser localization of lead in kidney tissue of poisoned rats. Nature, 227, 1056.

Chisolm, J. J. Jr. (1971). Lead poisoning. Scientific American, 224, No. 2, pp. 15-23.

Choie, D. D. and Richter, G. W. (1972). Lead poisoning: Rapid formation of intranuclear inclusions. Science, 177, 1194-1195.

Currier, R. D. and Haerer, A. F. (1968). Amyotrophic lateral sclerosis and metallic toxins. Archives of Environmental Health, 17, 712-719.

Gombault, A.(1873). Contributioná l'histoire anatomique de l'atrophie musculaire saturnine. Archives de Physiologie et normale pathologie, 5 (1st ser.) 592-597.

Goyer, R. A. (1971). Lead toxicity: a problem in environmental pathology. American Journal of Pathology, 64, 167-179.

and Krall, R. (1969). Ultrastructural transformation in mitochondria isolated from kidneys of normal and lead-intoxicated rats. Journal of Cell Biology, 41, 393-400.

_, Leonard, D. L., Moore, J. F., Rhyne, B., and Krigman, M. R. (1970). Lead dosage and the role of the intranuclear inclusion body. Archives of Environmental Health, 20, 705-711.

Haeger-Aronsen, B. (1971). An assessment of the laboratory tests used to monitor the exposure of lead workers. British Journal of Industrial Medicine, 28, 52-58.

Herter, C. A. (1895). Report of a case of lead paralysis with special reference to cytological changes in the nervous system and the distribution of lead. New York Medical Journal, 61, 664-667.

Kehoe, R. A. (1964). Normal metabolism of lead. Archives of Environmental Health, 8, 232-235.

, Cholak, J., and Story, R. V. (1940). A spectrochemical study of the normal ranges of concentration of certain trace metals in biological materials. Journal of Nutrition, 19, 579-592. 
Koeppe, D. E. and Miller, R. J. (1970). Lead effects on corn mitochondrial respiration. Science, 167, 13761378.

Krall, A. R., Pesavento, C., Harmon, S. J., and Packer, R. M. (1972). Elevation of norepinephrine levels and inhibition of mitochondrial oxidative phosphorylation in cerebellum of lead intoxicated suckling rats. Federation Proceedings, 31, abstracts 665.

Lane, R. E. (1949). The care of the lead worker. British Journal of Industrial Medicine, 6, 125-143.

McIntire, M. S. and Angle, C. R. (1972). Air lead: Relation to lead in blood of black school children deficient in glucose-6-phosphate dehydrogenase. Science, 177, 520-522.

Mellors, R. C. and Carroll, K. G. (1961). A new method for local chemical analysis of human tissue. Nature, 192, 1090-1092.

Patterson, C. C. (1965). Contaminated and natural lead environments of man. Archives of Environmental Health, 11, 344-359.

Pr̂erovská, I. and Teisinger, J. (1970). Excretion of lead and its biological activity several years after termination of exposure. British Journal of Industrial Medicine, 27, 352-355.

Robbins, S. L. (1963). Chemical and physical injuries. In Textbook of Pathology, 2nd edition, pp. 201-203. W. B. Saunders, Philadelphia.

Sauer, R. M., Zook, B. C., and Garner, F. M. (1970). Demyelinating encephalomyelopathy associated with lead poisoning in non-human primates. Science, 169, 1091-1093.

Simpson, J. A., Seaton, D. A., and Adams, J. F. (1964). Response to treatment with chelating agents of anaemia, chronic encephalopathy, and myelopathy due to lead poisoning. Journal of Neurology, Neurosurgery and Psychiatry, 27, 536-541.

Soman, S. D., Joseph, K. T., Raut, S. J., Mulay, C. D., Parameshwaran, M., and Panday, V. K. (1970). Studies on major and trace element content in human tissues. Health Physics, 19, 641-656.

Tousimis, A. J. (1963). Scanning electron probe microanalysis of biological specimens. In Proceedings of the First National Biomedical Sciences Instrumentation Symposium, edited by F. Alt, vol. 1, p. 249. Plenum Press, New York.

Warren, H. V., Delavault, R. E., and Christine, H. (1967). Possible correlations between geology and some disease patterns. Annals of the New York Academy of Sciences, 136, 657.

Weiner, L. P., Johnson, R. T., and Herndon, R. M. (1973). Viral infections and demyelinating diseases. New England Journal of Medicine, 288, 1103-1110.

White, J. M. and Harvey, D. R. (1972). Defective synthesis of $\alpha$ and $\beta$ globin chains in lead poisoning. Nature, 236, 71-73.

Wilson, S. A. K. (1907). The amyotropy of chronic lead poisoning: amyotrophic lateral sclerosis of toxic origin. Review of Neurology and Psychiatry, 5, 441-455.

Address correspondence to Dr. A. Petkau, Medical Biophysics Branch, Whiteshell Nuclear Research Establishment, Pinawa, Manitoba.

Received for publication 19 November 1973

Accepted for publication 21 December 1973 